\title{
Hemorrhoids: an experimental model in monkeys ${ }^{1}$
}

\author{
Hemorróidas: modelo experimental em macacos
}

\author{
Hélio Plapler ${ }^{2}$ \\ 1. Department of Surgery, Federal University of São Paulo (UNIFESP), São Paulo, Brazil. \\ 2. PhD, Associate Professor, UNIFESP, São Paulo, Brazil.
}

\begin{abstract}
Purpose: Hemorrhoids are a matter of concern due to a painful outcome. We describe a simple, easy and reliable experimental model to produce hemorrhoids in monkeys. Methods: 14 monkeys (Cebus apella) were used. After general anesthesia, hemorrhoids were induced by ligation of the inferior hemorrhoidal vein, which is very alike to humans. The vein was located through a perianal incision, dissected and ligated with a 3-0 vicryl. The skin was sutured with a 4-0 catgut thread. Animals were kept in appropriate cages and evaluated daily. Results: Nine days later there were hemorrhoidal piles in the anus in fifty percent (50\%) of the animals. Outcome was unremarkable. There was no bleeding and all animals showed no signs of pain or suffering. Conclusion: This is an affordable and reliable experimental model to induce hemorrhoids for experimental studies.
\end{abstract}

Key words: Hemorrhoids. Colorectal Surgery. Cebus.

\section{RESUMO}

Objetivo: Hemorróidas são objeto de preocupação devido à evolução dolorosa no pós-operatório. Descrevemos aqui um modelo experimental simples e confiável de indução de hemorróidas em macacos. Métodos: 14 macacos-prego (Cebus apella) foram empregados. Após anestesia geral induziu-se a formação de hemorróidas pela ligadura da veia hemorroidária inferior, que é muito parecida com a de humanos. A veia foi localizada através de uma incisão perianal, dissecada e ligada com fio de vicryl 3-0. A pele foi suturada com fio de categute 4-0. Os animais foram mantidos em jaulas apropriadas e avaliados diariamente. Resultados: Nove dias após o procedimento havia mamilos hemorroidários em cinqüenta por cento (50\%) dos animais. Não houve intercorrências no pós-operatório. Não houve sangramento ou sinais de dor ou de sofrimento. Conclusão: Este é um modelo viável e confiável para induzir hemorróidas para estudos experimentais.

Descritores: Hemorróidas. Cirurgia Colorretal. Cebus.

\section{Introduction}

More than $80 \%$ of the population suffers from hemorrhoids which are formed from the gradual congestion and hypertrophy of the hemorrhoidal veins. The straining effort promotes the congestion of the hemorrhoidal veins which quickly empty after feces pass by. As consequence of the intestinal constipation, the effort drawn out for straining keeps these veins out of the anus, aggravating and speeding up the development of the hemorrhoids; it also occurs during pregnancy and in the weightlifters by increase of the infraabdominal pressure. Heredity plays an important role, being common to observe many cases in a same family ${ }^{1,2}$. Many techniques were applied trying to keep the mucosa attached to the anal canal walls by means of fibrosis obtained through ischemic necrosis (rubber band) $)^{3,4}$, intense cold (cryosurgery) 3,5 or local heat (photocoagulation) $)^{1,6,7,8}$, by circular mechanical suture ${ }^{9,10}$ and laser ${ }^{11}$. Each of these methods depends on hemorrhoidal degree ${ }^{12}$. However, until now, all these therapeutic methods were performed in anima nobili because there was no any animal model as to be used to study them. Our purpose was to develop an experimental model for induction of hemorrhoids in primates for operative technique studies.

\section{Methods}

This project was approved by the Committee of Ethics in Research at UNIFESP/HSP, CER protocol number 0615102 and release license for capture, collect, transport and exposition gotten in the Brazilian Institute of the Environment and Renewable Natural Resources - IBAMA, under the protocol number 02027.007959/98-53. We used 14 male “nail-monkeys", species Cebus apella, 12-year-old average age, weighing between 3,5 and 4,5Kg; proceeding from the "Centro de Reabilitação Animal do Parque Ecológico do Tietê-DAEE”. Animals had been carried to the Veterinarian Hospital of Bandeirante University of São Paulo - UNIBAN, where they had been kept in individual cages, with appropriate food and water up to 8 hours before experiment. They were kept for 5 days to adapt to the new environment and the circadian rhythm was respected keeping adequate sanitary conditions. The animals were anesthetized with an IM injection of ketamin chloride $15 \mathrm{mg} / \mathrm{Kg}$, midazolan $0,5 \mathrm{mg} / \mathrm{Kg}$ and atropine sulphate $0,02 \mathrm{mg} / \mathrm{Kg}$; venous access through the cephalic vein was provided for fluid infusion $(10 \mathrm{ml} / \mathrm{Kg} / \mathrm{h})$. The animals were maintained with isofluorane and $100 \%$ oxygen $(1,5 \mathrm{~L} /$ minute) through a 3,5f tracheal tube. Animals were taken to the OR and 
placed in position. We used topic PVPI (Povidine ${ }^{\circledR}$ ) as antiseptic. Under general anesthesia, we performed a perineal incision to the edge of the external sphincter of the anus for the right side (Figure 1), isolated the inferior hemorrhoidal vein and ligated it with non absorbable 3-0 vicryl (Figure 2). The incision was closed with continuous suture with absorbable 4-0 catgut. Animals were examined daily to determine appearance of hemorrhoidal piles.

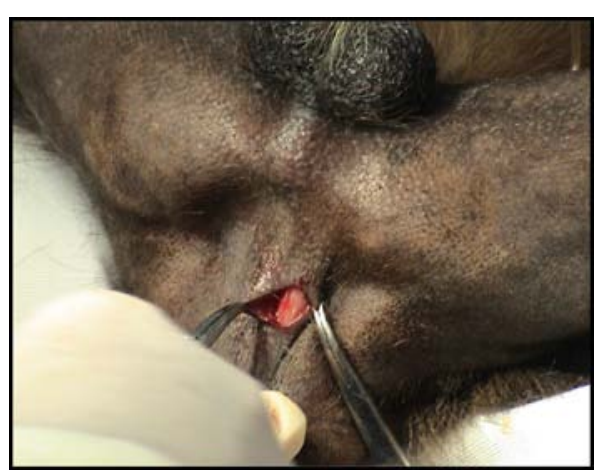

FIGURE 1 - Perianal incision and exposure

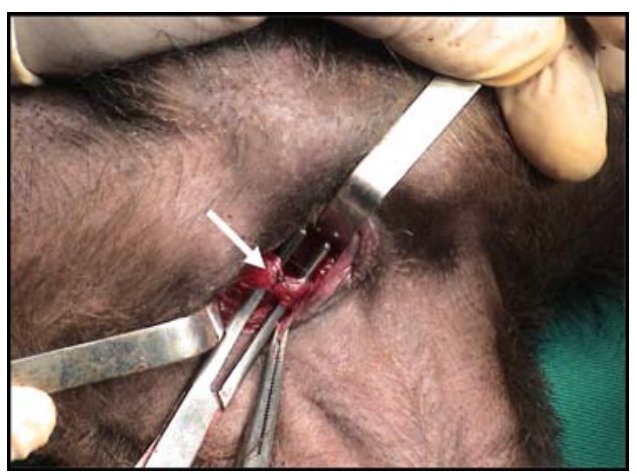

FIGURE 2 - The inferior hemorrhoidal vein (arrow) is isolated and tied

\section{Results}

The piles were identified (Figure 3) around P.O. day nine and they disappeared after two to three weeks. Seven out of fourteen animals (50\%) showed a hemorrhoidal pile. All had no sign of pain or any discomfort during the outcome. They were released at the end of the whole project to their original environment.

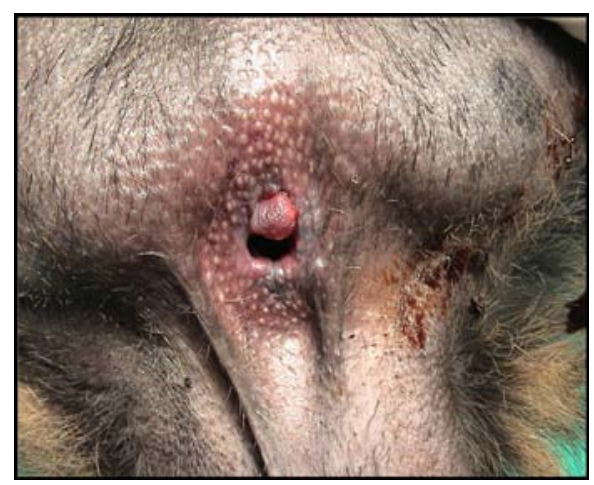

FIGURE 3 - Hemorrhoidal pile induced by tying the inferior hemorrhoidal vein (P.O. day 9)

\section{Discussion}

Since Milligan e Morgan described their surgical technique $^{13}$ there are discussions about which is the best method to treat hemorrhoids and until now there is no consensus on this matter. An experimental model in anima nobili is a matter of ethical concerns. Since there are no experimental animal models described in the literature, it was necessary to create an animal experimental model which allowed producing hemorrhoids and treating them as well. We did not find any anatomical description of the perineal region of the monkeys. Plapler, in a former study (not published) compared this region to human's perineal venous drainage and showed its resemblance (Figure 4). Histological analysis performed as a part of this preliminary study pointed that the colonic mucosa has a simple cylindrical epithelium, with absorption and caliciform cells. Into the lamina propia there is a loose connective tissue mainly with caliciform cells (Figures 5 and 6). The anal canal is covered by a no keratin stratified cylindrical epithelium and the lamina propria has many blood vessels. Due to this similarity and because monkeys stand up the same way as men do, we realized that this could be a good experimental protocol. Ligation of the inferior hemorrhoidal vein would lead to a decrease in venous drainage and cause hemorrhoids to grow up. However, many mechanisms play a role to produce hemorrhoids and just simply interrupting venous drainage do not explain how hemorrhoids appears, which is demonstrated by he fact that only $50 \%$ of the animals developed hemorrhoids. This percentage, however, allows considering this method as a good experimental model, as long as no other led to this result. Because this is an animal model it is not possible to evaluate parameters like pain, although the animals' behavior after surgery, suggests that there was no pain at all or any other kind of distress.
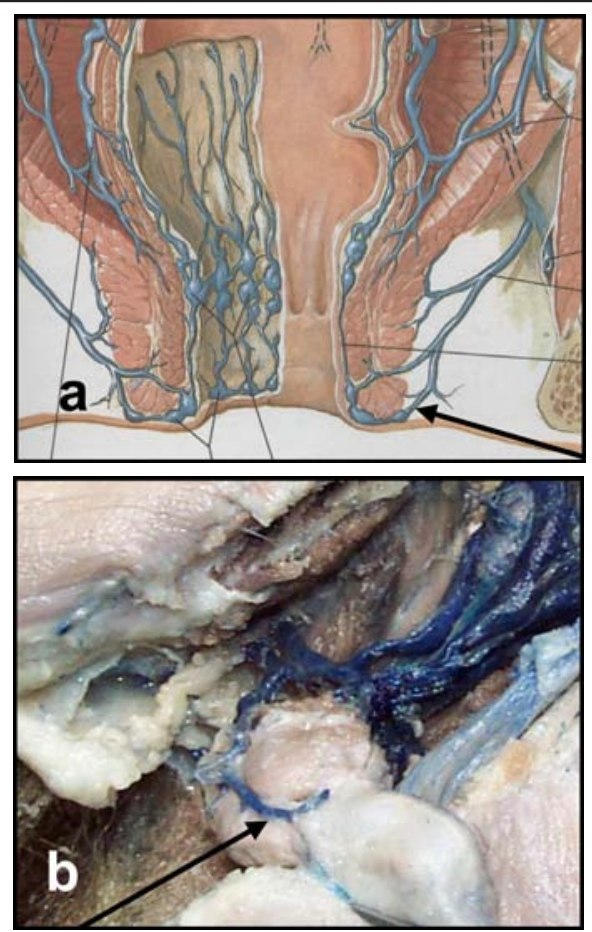

FIGURE 4 - Anal venous drainage: comparison between humans1 (a) and monkeys (b). Note the inferior hemorrhoidal vein (arrows) 

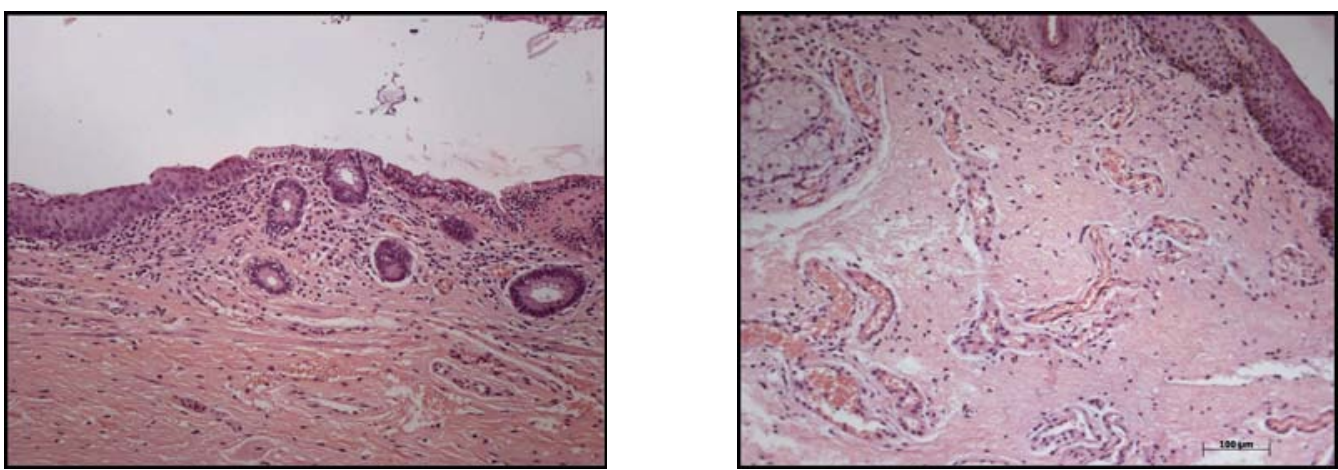

FIGURES 5 AND 6 - Anal canal region with a no keratin stratified cylindrical epithelium and the lamina propria with many blood vassels. H.E. $100 \mathrm{x}$

\section{Conclusion}

The method of hemorrhoid induction by inferior hemorrhoidal vein ligation in monkeys is feasible and is suitable as an animal model for hemorrhoids studies.

\section{References}

1. Abcarian II, Alexander-Williams J, Christiansen J, Johanson J, Killingback M, Nelson RL et al. Benign anotrectal disease: definition, characterization and analysis of treatment. Am J Gastroenterol. 1994;898:182.

2. Keighley MRB, Williams NS. Surgery of the anus, rectum and colon. London: WB Saunders; 1993.

3. Rudd WWH. Ligation and cryosurgery of all hemorrhoids: an office produce. Int Surg. 1989;74:148-51.

4. Tajana A. Hemorrhoidectomy according to MilliganMorgan: ligadure and excision technique. Int Surg. 1989;74:158-61.

5. Tanaka S. Cryosurgical treatment of hemrrhoids in Japan. Int Surg. 1989;74:146-7.

6. Reis Neto JA, Quilici FA, Cordeiro F, Reis Jr JA Ambulatory treatment of hemorrhoids: a prospective random trial. Coloproctology. 1992;14:342.

7. Newstead CL. Ambulatory treatment of benign anal diseases. In: Reis Neto JA. New trends in coloproctology. Brasil: Revinter; 2000. p.197.
8. Neiger A. Infrared-photo-coagulation for hemorrhoids treatment. Int Surg. 1989;74:142-3.

9. Ganio E, Lus AR, Trompetto M, Clerico CI. Stapled haeorrhoidectomy. In: Reis Neto JA. New trends in coloproctology. Brasil: Revinter; 2000. p.207.

10. Longo A. Treatment of haemorrhoids disease by reduction of mucosa and hemorrhoidal prolapse with circular suturing device: a new procedure. VI World Congress of Endoscopy Surgery, Rome; 1998. p777.

11. Fleshman J. Advanced technology in the management of hemorroids: stapling, laser, harmonic scalpel, and ligasure. J Gastrointest Surg. 2002;6:299-301.

12. Ferguson Jr EF. Alternatives in the treatment of hemorrhoidal disease. South Med J. 1988;81:606-10.

13. Milligan, ETC, Morgan, CN. Surgical anatomy of the anal canal and the operative treatment of hemorrhoids. Lancet. 1937;2:1120-5.

\section{Acknowledgements}

We are especially grateful to Professor Dr. José Alberto da Silva, Director of Veterinary Hospital - Universidade Bandeirante, São Paulo, Brazil; Professor Márcia Bento Moreira, from Universidade Bandeirante, São Paulo, Brazil; Dr. Liliane Millanello and Dr. Melissa Alves, Veterinarians from Parque Estadual do Tietê, São Paulo, Brazil.

\section{Correspondence:}

Hélio Plapler

Rua Tomas Carvalhal, 884/51

04006-003 São Paulo - SP Brazil

helio@plapler.com.br
Conflict of interest: none Financial source: FAPESP Protocol \#03/06720-3

Received: April 11, 2006

Review: May 09, 2006

Accepted: June 13, 2006

\section{How to cite this article:}

Plapler H. Hemorrhoids: an experimental model in monkeys. Acta Cir Bras. [serial on the Internet] 2006 Sept-Oct;21(5). Available from URL: http://www.scielo.br/acb. 